\title{
PENGEMBANGAN LEMBAR KERJA SISWA (LKS) BERBASIS PROBLEM BASED LEARNING PADA MATERI BILANGAN DI KELAS VII SMP NEGERI 22 KOTA JAMBI
}

\author{
Sri Yulia ${ }^{1}$ Buyung $^{2}$, Relawati ${ }^{3}$ \\ Program Studi Pendidikan Matematika, FKIP, Universitas Batanghari ${ }^{1,2,3}$ \\ Jl. Slamet Riyadi No.1 Broni Jambi \\ e-mail: -
}

\begin{abstract}
ABSTRAK
Produk dikembangkan dalam bentuk Lembar Kerja Siswa (LKS) matematika pada materi angka untuk SMP kelas VII dengan model pembelajaran berbasis masalah. Model pengembangan yang digunakan adalah model ADDIE terdiri dari beberapa tahapan: Analisis, Desain, Pengembangan, Implementasi, dan Evaluasi. Validasi dilakukan oleh 2 ahli materi, ahli desain dan ahli media. Lembar Kerja Siswa (LKS) yang dikembangkan diuji dalam 3 tahap, satu lawan satu pelajar dengan 3 mata pelajaran, uji coba kelompok kecil) dengan subjek 6 siswa, uji coba lapangan (uji coba lapangan) dengan subjek 36 siswa . Hasil penelitian menunjukkan bahwa Lembar Kerja Siswa (LKS) masalah berdasarkan pembelajaran berbasis masalah berdasarkan penilaian: 1) ahli materi memperoleh total ratarata 3,98 termasuk dalam kategori "Baik" dan jika persentasenya mendapatkan nilai $80 \%$ sehingga termasuk dalam kategori "Valid". 2) ahli desain memperoleh total rata-rata 4,00 yang termasuk dalam kategori "Baik" dan dalam persen mendapatkan nilai $80 \%$ sehingga termasuk dalam kategori "Valid". 3) ahli media memperoleh total rata-rata 4,83 yang termasuk dalam kategori "Sangat Baik" dan dalam persentase skor 97\% sehingga termasuk dalam kategori "Sangat Valid". Penilaian siswa dilakukan dalam 3 tahap: 1) uji coba individu memperoleh total rata-rata 4,55 yang termasuk dalam kategori "Sangat Baik" dan dalam persentase skor 91\% sehingga termasuk kategori "Sangat Valid", 2) uji coba kelompok kecil diperoleh total rata-rata 4,65 yang termasuk dalam kategori "Sangat Baik" dan dalam persen mendapat nilai 93\% sehingga kategori "Sangat Valid", 3) uji coba lapangan diperoleh ratarata total 4,64 yang termasuk dalam kategori "Sangat Baik" dan dalam skor persen 92\% sehingga termasuk dalam kategori "Sangat Valid". Dengan demikian, Lembar Kerja Siswa (LKS) berdasarkan pembelajaran berbasis masalah pada materi angka di kelas VII dinyatakan valid dan praktis sehingga layak digunakan dalam proses pembelajaran oleh guru dan siswa SMP terutama siswa nomor materi.
\end{abstract}

Kata kunci:

Pengembangan; Pembelajaran Berbasis Masalah, ADDIE; Lembar Kerja Siswa (LKS).

\begin{abstract}
Products developed in the form of Student Worksheet (LKS) mathematics on the number material for SMP class VII with problem based learning model. The development model used is the ADDIE model consists of several stages: Analyze, Design, Development, Implementation, and Evaluation. Validation was done by 2 material experts, design experts and media experts. The Student Working Sheet $(L K S)$ developed was tested in 3 stages, one to one learner with 3 subjects, small group trial try-out) with the subject of 6 students, field trial (field try-out) with the subject of 36 students. The results showed that the Student Worksheet (LKS) problem based on problem based learning based on the assessment: 1) the material experts obtained the average total of 3.98 included in the category of "Good" and if the percentage get $80 \%$ value so that included in the category "Valid ". 2) design experts obtained an average total of 4.00 which is included in the category of "Good" and in percent get the value of $80 \%$ so that included in the category "Valid". 3) media experts obtained an average total of 4.83 which is included in the category of "Very Good" and in percent score $97 \%$ so that included in the category of "Very Valid". Student assessments were conducted in 3 stages: 1) individual trials obtained an average total of 4.55 that belonged to the category
\end{abstract}




\begin{abstract}
of "Very Good" and in percent score of $91 \%$ so that included "Very Valid" category, 2) small group trial obtained total average of 4.65 which belongs to the category of "Very Good" and in percent get $93 \%$ value so that the category "Very Valid", 3) field trial obtained the average total 4.64 which belongs to the category "Very Good" and in percent score of 92\% so it belongs to the category of "Very Valid". Thus, Student Worksheet (LKS) based on problem based learning on the number material in class VII is declared valid and practical so feasible to be used in the learning process by teachers and junior high school students especially material number.
\end{abstract}

Keywords:

Development; Problem Based Learning, ADDIE; Student Worksheet (LKS).

\section{PENDAHULUAN}

Matematika merupakan salah satu komponen pendidikan dasar dalam bidang-bidang pengajaran yang diperlukan untuk proses perhitungan dan proses berfikir yang sangat dibutuhkan orang dalam menyelesaikan berbagai masalah (Susanto, 2013). Matematika bukanlah sekedar bagaimana cara mengerjakan soal tetapi bagaimana menalar hubunganhubungan yang berlaku dikehidupan sehari-hari.

Matematika juga merupakan suatu mata pelajaran yang digunakan untuk berkomunikasi, berfikir kreatif dan kemampuan memecahkan masalah. Agar dapat terciptanya pembelajaran matematika yang komunikatif, para pendidik juga harus memberikan kesempatan kepada peserta didik untuk berperan aktif dan mandiri dalam setiap pembelajaran. Para pendidik perlu mengembangkan kreatifitas untuk merencanakan, menyiapkan, dan membuat bahan ajar yang kaya inovasi sehingga menarik bagi peserta didik.Salah satunya, para pendidik perlu membangun kreativitas agar mampu membuat bahan ajar yang inovatif.

Menurut Lestari (2013) mengatakan bahwa bahan ajar adalah seperangkat sarana atau alat pembelajaran yang berisikan materi pembelajaran, metode, batasan-batasan, dan cara mengevaluasi yang didesain secara sistematis dan menarik dalam rangka mencapai tujuan yang diharapkan yaitu mencapai kompetensi atau subkompetensi.Bahan ajar yang memiliki peran yang besar dalam proses pembelajaran yaitu Lembar Kerja Siswa (LKS), karena Lembar Kerja Siswa (LKS)dapat membantu guru untuk mengarahkan siswa memecahkan masalah melalui aktivitasnya sendiri.

Berdasarkan observasi ke SMP Negeri 22 Kota Jambi pada tanggal 18 Februari 2016. Lembar Kerja Siswa (LKS) yang dimiliki oleh siswa masih memiliki kekurangan yaitucontoh soal pada Lembar Kerja Siswa (LKS) masih kurang dilengkapi langkah kerja yang terstruktur, soal latihan yang disajikan belum mengaitkan pada keadaan nyata dalam kehidupan sehari-hari dan strategi/model pembelajaran belum terlihat. Pengemasan materi yang sedemikian menyebabkan siswa biasanya menghafal rumus atau materi tanpa pemahaman memecahkan masalah. Bahan ajar berupa Lembar Kerja Siswa (LKS) yang digunakan bukanlah hasil rancangan guru sendiri, melainkan Lembar Kerja Siswa (LKS) yang dibeli dari penerbit. Lembar Kerja Siswa (LKS) yang digunakan pada saat proses pembelajaran sebaiknya rancangan guru sendiri karena akan lebih menarik dan mengesankan bagi peserta didik.

Berdasarkan hasil pengamatan penulis terhadap Lembar Kerja Siswa (LKS) SMP Negeri 22 Kota Jambi bahwa Lembar Kerja Siswa (LKS) yang dimiliki siswa memiliki beberapa kekurangan diantaranya adalah dari segi bahasa, desain grafis, dan strategi/model pembelajaran. Segi bahasa masih belum dipahami siswa 


\section{$\pi$ (Phi)}

karena bersifat simbolik tanpa mengaitkan soal dalam kehidupan sehari-hari. Dari desain grafis, tidak adanya warna yang dikombinasikan dalam Lembar Kerja Siswa (LKS) sehingga kurang menarik minat siswa dalam mempelajarinya. Dari segi model pembelajaran, Lembar Kerja Siswa (LKS) yang digunakan belum menunjukkan langkah kerja yang sistematis. Lembar Kerja Siswa (LKS) tersebut kurang sesuai dengan Kurikulum 2013 karena pada tahun ajaran 2016/2017 di SMP Negeri 22 Kota Jambi baru akan menerapkan Kurikulum tersebut dari yang semula menggunakan Kurikulum KTSP. Lembar Kerja Siswa (LKS) harus sesuai dengan karakter siswa yang mengharuskan siswa untuk aktif dalam kegiatan belajar, berani mengungkapkan ide menggunakan bahasanya sendiri, dan penuh rasa ingin tahu dalam permasalahan yang ada.

Menurut Trianto (2007) bahwa Lembar Kerja Siswa adalah panduan siswa yang digunakan untuk melakukan kegiatan penyelidikan atau pemecahan masalah. Lembar Kerja Siswa (LKS) berupa panduan untuk latihan pengembangan aspek kognitif. Sedangkan menurut Prastowo (2011) Lembar kerja siswa (Student Work Sheet) adalah lembaranlembaran berisi tugas yang harus dikerjakan oleh peserta didik. Lembar Kerja Siswa biasanya berupa petunjuk atau langkah-langkah untuk menyelesaikan suatu tugas sesuai dengan kompetensi dasar yang akan dicapai.

Dalam hal ini, perlu adanya pengembangan Lembar Kerja Siswa (LKS) yang bisa menunjang proses pembelajaran dalam pemecaham masalah. Agar Lembar Kerja Siswa (LKS) yang dipelajari siswa tersusun sistematis maka diperlukan suatu model pembelajaran yang berkaitan dengan pengalaman siswa sehari-hari. Salah satu model pembelajaran yang sesuai dengan pemecahan masalah adalah model pembelajaran Problem Based Learning.
Jurnal Pendidikan Matematika

Volume 2 Nomor 1 Tahun 2018
Problem Based Learning adalah
suatu model pembelajaran yang melibatkan siswa untuk memecahkan suatu masalah yang berkaitan dengan kehidupan sehari-hari. Pembelajaran berbasis masalah (Problem Based Learning) adalah pemprosesan informasi siswa dalam menangani situasi lingkungan, mengorganisasi data, melihat masalah, mengembangkan konsep dan memecahkan masalah.

Menurut Ward (Ngalimun, 2015)

Problem Based Learning (PBL) merupakan model pembelajaran inovatif yang dapat memberikan kondisi belajar aktif kepada siswa.Problem Based Learning adalah suatu salah satu model pembelajaran yang melibatkan siswa untuk memecahkan suatu masalah melalui tahap-tahap metode ilmiah sehingga siswa dapat mempelajari pengetahuan yang berhubungan dengan masalah tersebut.

Problem Based Learningmerupakan model pembelajaran yang bertujuan merangsang peserta didik untuk belajar melalui berbagai permasalahan nyata dalam kehidupan sehari-hari, dihubungkan dengan pengetahuan yang dipelajarinya (Mulyasa, 2014).

Menurut Delisle (Abidin, 2014) model pembelajaran berbasis masalah merupakan model pembelajaran yang dikembangakan untuk membantu guru mengembangkan kemampuan berfikir dan keterampilan memecahkanmasalah pada siswa selama mereka mempelajari materi pembelajaran. Menurut Torp dan Sage (Abidin, 2014) bahwa model pembelajaran berbasis masalah merupakan model pembelajaran yang difokuskan untuk menjembatani siswa agar beroleh pengalaman belajar dalam mengorganisasikan, meneliti, dan memecahkan masalah-masalah kehidupan yang kompleks. Problem Based Learning merupakan pembelajaran yang penyampaian materinya dilakukan dengan 


\section{$\pi$ (Phi)}

cara menyajikan suatu masalah, mengajukan pertanyaan-pertanyaan, memfasilitasi penyelidikan dan membuka dialog.

Materi yang akan dikembangakan dalam Lembar Kerja Siswa (LKS) ini adalah bilangan. Bilangan adalah suatu konsep matematika yang digunakan untuk pencacahan dan pengukuran. Pada setiap jenjang pendidikan, materi bilangan selalu diajarkan kepada siswa dengan tingkat kesulitan yang berbeda-beda. Bagi siswa SMP, materi bilangan terdiri dari bilangan bulat dan bilangan pecahan. Dengan memahami sifat-sifat operasi hitung pada materi bilangan bulat dan pecahan, siswa mampu menyelesaikan masalah dalam kehidupan sehari-hari yang berkaitan dengan konsep bilangan.

\section{METODE PENELITIAN}

Jenis penelitian ini menggunakan pendekatan kualitatif dan metode yang digunakan adalah metode penelitian dan pengembangan. Metode penelitian dan pengembangan adalah metode penelitian yang digunakan untuk menghasilkan produk tertentu, dan menguji keefektifan produk tersebut.

Perencanaan pengembangan Lembar Kerja Siswa (LKS) dengan model ADDIE menurut Branch (2009) dengan langkahlangkah (1) Analyze (Analisis); (2) Design (Perancangan);

(Pengembangan);

Development (Pelaksanaan); (5) Evaluation (Evaluasi); (6) Validasi, Evaluasi dan Revisi Produk.

Pengumpulan data dalam penelitian ini dilaksanakan dengan cara sebagai berikut :

\section{Tahap Persiapan}

Tahap persiapan pada penelitian pengembangan Lembar Kerja Siswa (LKS) berbasis problem based learning terdiri atas: a) Mempersiapkan produk Lembar Kerja Siswa (LKS), b) Menyiapkan surat izin penelitian, c) Menentukan tim ahli sebagai validator, d)
Menentukan siswa sebagi subjek uji coba.

\section{Tahap Pelaksanaan}

Tahap Tahap persiapan pada penelitian pengembangan Lembar Kerja Siswa (LKS) berbasisproblem based learning adalah Penulis menunjukkan Lembar Kerja Siswa (LKS) yang telah dibuat kepada tim ahli (validator). Kemudian tim ahli memvalidasi Lembar Kerja Siswa (LKS) yang telah dibuat melalui angket tertutup dengan menyertakan komentar dan saran dalam perbaikan LKS tersebut, setelah Lembar Kerja Siswa (LKS) dinyatakan layak, Lembar Kerja Siswa (LKS) tersebut di uji cobakan kepada siswa.

\section{Tahap Akhir}

Setelah Lembar Kerja Siswa (LKS) diuji cobakan kepada siswa diperoleh data kualitatif dan data kuantitatif Menganalisis data kualitatif dan kuantitatif dari hasil yang diperoleh sesuai dengan teknik analisis data.

Dalam penelitian pengembangan ini, jenis data yang diambil berupa data kuantitatif dan data kualitatif.

\section{Analisis Data Kuantitatif}

Data yaitu data yang berupa skor penilaian. Data kuantitatif diperoleh dari hasil penilaian tim ahli, tanggapan guru dan angket presepsi siswa terhadap Lembar Kerja Siswa (LKS). Data kuantitatif ini dijadikan penentu kualitas dari produk yang dikembangkan ditinjau dari aspek kevalidan, dan kepraktisan.

\section{Analisis Data Kualitatif}

Data kualitatif diperoleh dari validator yaitu tim ahli materi, tim ahli media dan tim ahli desain berupa isian angket dengan komentar dan saran perbaikan produk Lembar Kerja Siswa (LKS).Lembar Kerja Siswa (LKS) yang dihasilkan dikatakan valid jika minimal tingkat validitas untuk masing-masing tiap perangkat pembelajaran 


\section{$\pi$ (Phi)}

yang dicapai adalah kategori valid.

Analisis tingkat kepraktisan Lembar Kerja Siswa (LKS) dilihat dari hasil perhitungan kuantitatif angket respon siswa, dan berupa tanggapan siswa terhadap bahan ajar yang dikembangkan. Lembar Kerja Siswa (LKS) dikatakan praktis jika respon terhadap pembelajaran menggunakan perangkat yang dikembangkan minimal dikategorikan baik. Data kualitatif ini digunakan sebagai pedoman untuk melakukan revisi produk yang dikembangkan.

\section{HASIL DAN PEMBAHASAN}

Hasil penelitian pengembangan ini berupa (1) sebuah Lembar Kerja Siswa (LKS) berbasis problem based learning pada materi Bilangan kelas VII SMP, (2) penilaian Lembar Kerja Siswa (LKS) oleh ahli materi, ahli desain dan ahli media, (3) presepsi siswa dalam uji coba perorangan, uji coba kelompok kecil dan uji coba lapangan dengan revisi sesuai saran dibeberapa bagian. Berikut diagram penilaian hasil validasi materi untuk setiap aspek.

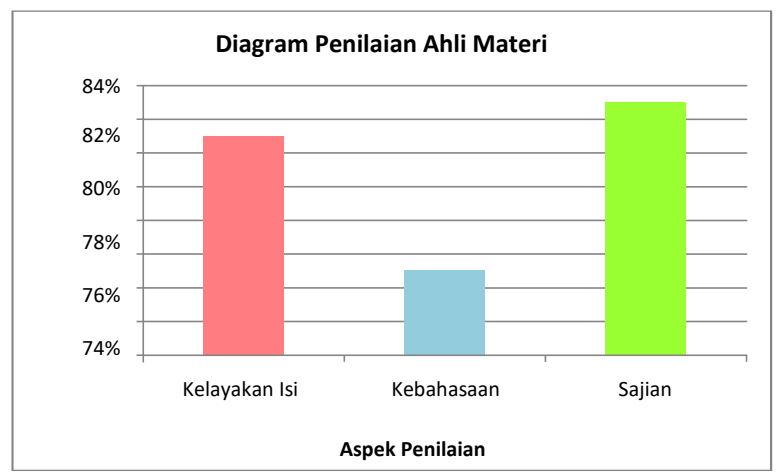

Gambar 1. Diagram Penilaian Ahli Materi

Berdasarkan diagram penilaian ahli materi pada angket kedua, dilihat dari aspek kelayakan isi diperoleh presentase $81 \%$ dengan kategori "sangat valid", aspek kebahasaan diperoleh presentase $73 \%$ dengan kategori "valid", dan aspek sajian diperoleh presentase $83 \%$ dengan lapangan terhadap Lembar Kerja Siswa (LKS) yang dikembangkan.

\section{Validasi Tim Ahli}

Pada tahap ini Lembar Kerja Siswa (LKS) divalidasi oleh dua orang ahli materi, satu orang ahli desain, dan satu orang ahli media. Adapun data validator yang akan memberikan penilaian pada perangkat pembelajaran.

\section{Validasi Materi}

Hasil analisis data pada validasi pertama, ahli materi menilai dan mengomentari serta memberikan saran, baik tulisan maupun lisan yang bertujuan untuk menghasilkan suatu produk Lembar Kerja Siswa (LKS) yang layak untuk diujicoba. Hasil validasi oleh ahli materi secara keseluruhan menilai produk diperoleh skor 104 yang berada dalam kategori "valid" dan layak untuk uji coba

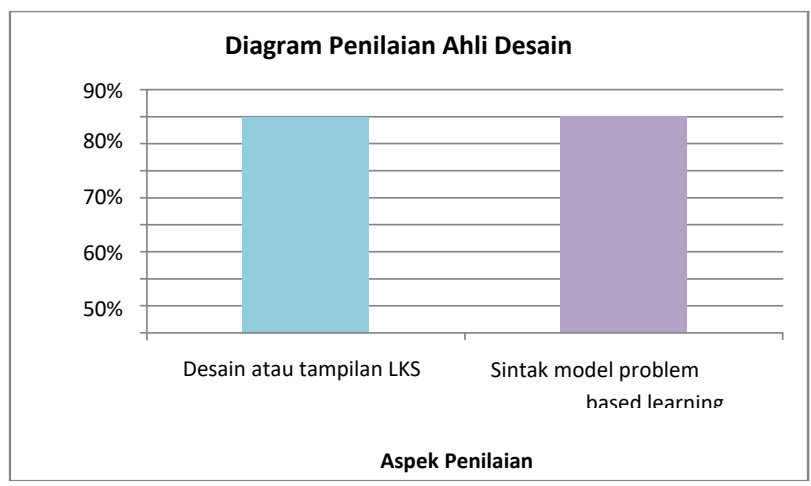

Gambar 2. Diagram Penilaian Ahli Materi Desain kategori "sangat valid".

\section{Validasi Desain}

Hasil analisis data pada validasi oleh ahli desain secara keseluruhan menilai produk diperoleh skor 40 berada dalam kategori "valid" dan layak untuk uji coba lapangan dengan revisi sesuai saran dibeberapa bagian. 


\section{$\pi$ (Phi)}

Berdasarkan diagram penilaian ahli desain pada gambar 2 pada angket kedua, dilihat dari aspek desain atau tampilan LKS diperoleh presentase $80 \%$ dengan kategori "valid", aspek sintak model problem based learning diperoleh presentase $80 \%$ dengan kategori "valid".

\section{Validasi Media}

Hasil analisis data pada validasi oleh ahli mediasecara keseluruhanmenilai produk diperoleh skor 116 berada dalam kategori "sangat valid".

tinggi, sedang dan rendah. Pemilihan siswa yang menjadi subjek uji coba perorangan dibantu oleh guru matematika yang mengajar dikelas tersebut yang mengetahui kemampuan matematika siswa dikelas VII C.

Teknik pelaksaaannya adalah Siswa diminta untuk mengoreksi Lembar Kerja Siswa (LKS) berdasarkan keterbacaan tulisan dan penggunaan font.Setelah di koreksi, kemudian siswa memberi penilaian pada angket yang telah disediakan.Adapun hasil ujicoba perorangan peraspek. Hasil analisis data ujicoba perorangan subjek ujicoba sebanyak 3 orang, siswa menilai produk dengan jumlah skor 164, dalam kategori

Diagram Penilaian Ahli Media

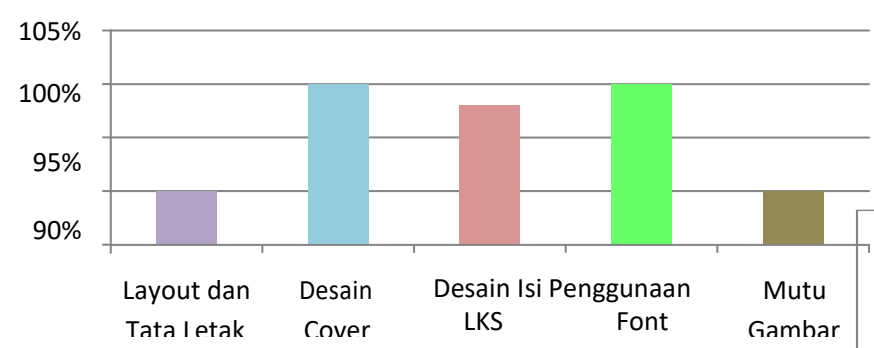

Aspek Penilaian

Gambar 3. Diagram Penilaian Ahli Media

Berdasarkan diagram penilaian ahli media pada angket kedua,dilihat dari aspek layout dan tata letak diperoleh presentase $90 \%$ dengan kategori "sangat valid", aspek desain cover diperoleh presentase 98\% dengan kategori "sangat valid", aspek penggunaan font diperoleh presentase $100 \%$ dengan kategori "sangat valid", dan aspek mutu gambar diperoleh presentase 90\% dengan kategori "sangat valid".

\section{Uji coba perorangan (One To One Learner)}

Tujuan uji coba perorangan dilakukan yaitu memberikan masukan awal peneliti terhadap Lembar Kerja Siswa (LKS) yang akan dikembangkan. Subjek ujicoba dilakukan pada ujicoba perorangan sebanyak 3 orang siswa di kelas VII C yang memiliki kemampuan "sangat valid". Berikut diagram hasil tanggapan siswa uji coba perorangan untuk setiap aspek:

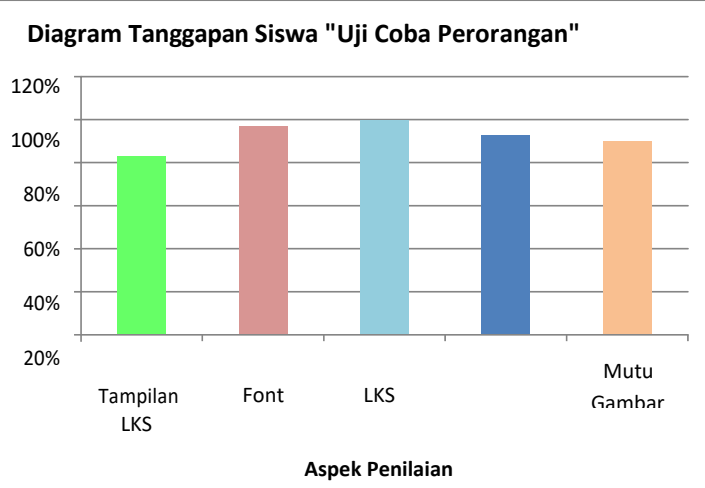

Gambar 4. Diagram Tanggapan Siswa Uji Coba Perorangan

Berdasarkan diagram tanggapan siswa uji coba perorangan, dapat disimpulkan bahwa aspek desain atau tampilan LKS diperoleh presentase 83\% dengan kategori "sangat valid", aspek penggunaan font diperoleh presentase 97\% dengan kategori "sangat valid", aspek desain isi LKS diperoleh presentase 100\% dengan kategori "sangat valid", dan aspek bahasa diperoleh presentase 93\% dengan kategori "sangat valid" dan mutu gambar diperoleh presentase $90 \%$ dengan kategori "sangat valid".

2. Uji Coba Kelompok Kecil (Small 


\section{$\pi$ (Phi)}

Group Try-out)

Setelah dilakukan uji coba perorangan, selanjutnya dilakukan uji coba kecil dengan tujuan memberi masukan kepada peneliti terhadap Lembar Kerja Siswa (LKS) yang dikembangkan.Uji coba kelompok kecil ini dilakukan kepada 6 orang siswa kelas VII B. Teknik pelaksaaannya adalah Siswa diminta memberikan penilaian terhadap Lembar Kerja Siswa (LKS) yang dikembangkan, berupa angket tanggapan siswa yang berisi 9 pertanyaan. Sebelum mengisi angket, siswa diberi penjelasan dalam mengisinya. Adapun hasil ujicoba kelompok kecil peraspek.

Analisis data ujicoba kelompok kecil subjek sebanyak 6 orang, siswa menilai produk dengan jumlah skor 164, dalam kategori "sangat valid".Berikut diagram hasil tanggapan siswa uji coba kelompok kecil untuk setiap aspek:

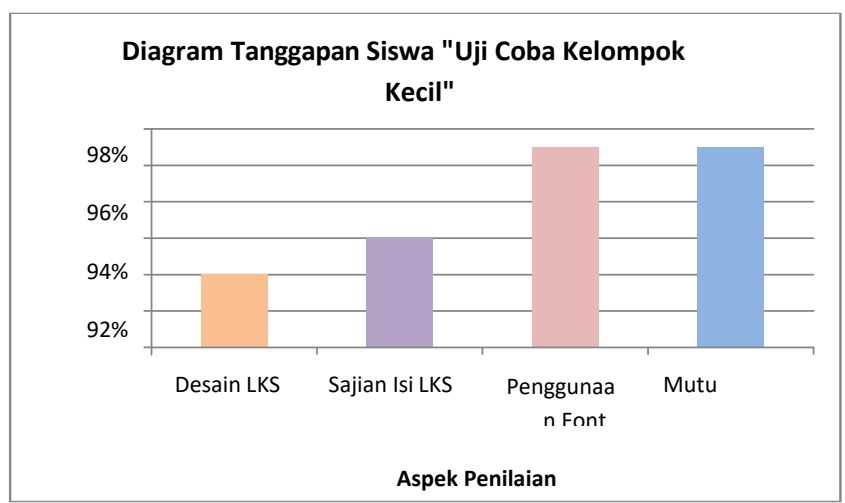

Gambar 5. Diagram Tanggapan Siswa Uji Coba Kelompok Kecil

Berdasarkan diagram tanggapan siswa uji coba kelompok kecil, dapat disimpulkan bahwa aspek desain LKS diperoleh presentase $90 \%$ dengan kategori "sangat valid", aspek sajian isi LKS diperoleh presentase $92 \%$ dengan kategori "sangat valid", aspek penggunaan font diperoleh presentase 97\% dengan kategori "sangat valid", dan aspek mutu gambar diperoleh presentase 97\% dengan kategori "sangat valid".

\section{Implementation (Pelaksanaan)}

Pada tahap implementasi, Lembar Kerja Siswa (LKS) berbasis problem based learning diimplementasikan di kelas sesungguhnya yaitu kelas VII A SMP Negeri 22 Kota Jambi dengan jumlah siswa adalah 36 orang. Lembar Kerja Siswa (LKS) berbasis problem based learning digunakan dalam proses pembelajaran. Kegiatan pembelajaran dilakukan selama 3 kali pertemuan yang terdiri atas 3 jam pelajaran dalam satu kali pertemuan.

Setelah dilakukan ujicoba, siswa secara umum menyatakan bahwa Lembar Kerja Siswa (LKS) menarik, langkah kerja mudah dipahami, soal latihan mudah dipahami, dan menambah wawasan siswa dalam belajar serta menjalin kerjasama antar kelompok. Analisis data ujicoba lapangan subjek sebanyak 36 orang, ujicoba dilakukan untuk melihat presepsi siswa terhadap produk dengan jumlah skor 2978, dalam kategori "sangat valid". Berikut diagram hasil tanggapan siswa uji coba lapangan untuk setiap aspek:

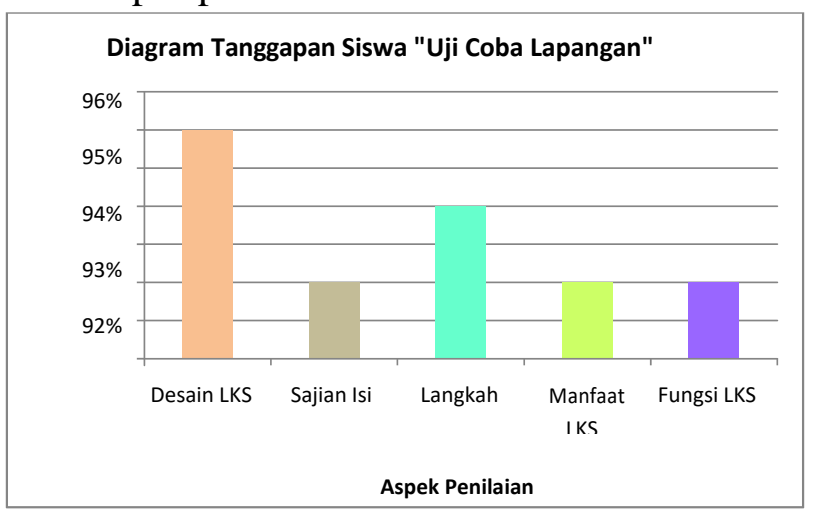

Gambar 6. Diagram Tanggapan Siswa Uji Coba Lapangan

Berdasarkan diagram tanggapan siswa uji coba kelompok kecil, dapat disimpulkan bahwa aspek desain LKS diperoleh presentase $95 \%$ dengan kategori "sangat valid", aspek sajian isi LKS diperoleh presentase $91 \%$ dengan kategori "sangat valid", aspek langkah kerja PBL 


\section{$\pi$ (Phi)}

diperoleh presentase 94\% dengan kategori "sangat valid", aspek manfaat LKS diperoleh presentase $91 \%$ dengan kategori "sangat valid", dan aspek fungsi LKS diperoleh presentase $92 \%$ dengan kategori "sangat valid". Hasil analisis data yang telah diperoleh dari penilaian Lembar Kerja Siswa (LKS) data respon siswa yang diperoleh kriteria sangat baik dari uji coba produk, maka dapat disimpulkan bahwa Lembar Kerja Siswa (LKS) yang dikembangkan memenuhi kriteria praktis. Bahan ajar Lembar Kerja Siswa (LKS) termasuk kategori “ sangatbaik" digunakan dalam proses pembelajaran materi Bilangan.

\section{SIMPULAN DAN SARAN}

Berdasarkan hasil penelitian pengembangan dan pembahasan terkait bahan ajar berupa Lembar Kerja Siswa (LKS) berbasis problem based learning pada materi Bilangan di kelas VII SMP Negeri 22 Kota Jambi yang telah dikembangkan maka dapat disimpulkan, yaitu:

1. Mengembangkan Lembar Kerja Siswa (LKS) berbasis problem based learning dilakukan dengan beberapa tahapan yaitu analyze, design, development, implementation dan evaluation. Pada tahap analyze peneliti melakukan observasi untuk mengetahui kurikulum yang digunakan disekolah, menganalisis karakter peserta didik dan menganalisis materi. Pada tahap design, peneliti membuat hal yang dibutuhkan meliputi persiapan pembuatan produk, penyusunan kerangka desain Lembar Kerja Siswa (LKS), serta penyusunan instrumen penilaian.Pada tahap development, peneliti membuat produk Lembar Kerja Siswa (LKS),kemudian divalidasi oleh 2 orang validator materi, validator desain dan validator media.Setelah Lembar Kerja Siswa (LKS) dinyatakan layak, selanjutnya diuji cobakan pada

uji coba perorangan yang terdiri dari 3 orang siswa kelas VII C, dan uji coba kelompok kecil terdiri dari 6 orang siswa kelas VII B.Pada tahap implementation Lembar Kerja Siswa (LKS) diuji cobakan pada situasi belajar sesungguhnya yaitu uji coba lapangan yang terdiri dari 36 orang siswa kelas VII A. Uji coba lapangan bertujuan untuk mengetahui presepsi siswa terhadap Lembar Kerja Siswa (LKS) dari aspek kepraktisan. Pada tahap evaluationdilakukan analisis hasil penilaian dari validator materi, validator desain, dan validator media berdasarkan validasi pertama.

2. Kualitas Lembar Kerja Siswa (LKS) berdasarkan aspek kevalidan dan aspek kepraktisan adalah sebagai berikut:

a) Berdasarkan hasil validasi tim ahli materidiperoleh total rata- rata 3,98 yang termasuk kategori baik dan jika dipersentasekanmendapat nilai $80 \%$ berada pada kategori "valid". Tim ahli desain diperoleh total ratarata 4,00 termasuk kategori baik dan jika dipersentasekan mendapat nilai $80 \%$ berada pada kategori "valid". Dan ahli media diperoleh total rata-rata 4,83 termasuk kategori sangat baik dan jika dipersentasekan mendapat nilai menunjukkan persentase $97 \%$ berada pada kategori "sangat valid". Sehingga dapat disimpulkan bahwa kualitas Lembar Kerja Siswa (LKS) berbasis problem based learning pada materi Bilangan dalam kategori valid dan layak untuk implementasikan.

b) Kepraktisan Lembar Kerja Siswa (LKS) berbasis problem based learning pada materi bilangan dilihat dari presepsi siswa melalui angket yang diberikan. Hasil uji coba menunjukkan presepsi siswa terhadap Lembar Kerja Siswa (LKS) sangat baik, positif serta 


\section{$\pi$ (Phi)}

menambah wawasan siswa dalam mempelajari materi Bilangan serta terjalinnya komunikasi yang baik dalam kerja sama kelompok. Hal ini dapat lihat berdasarkan hasil uji coba perorangan yang memperoleh persentase $91 \%$ dalam kategori "sangat valid", hasil uji coba kelompok kecil memperoleh persentase $93 \%$ dalam kategori "sangat valid", dan hasil uji coba lapangan memperoleh persentase $92 \%$ dalam kategori "sangat valid". Secara keseluruhan diperoleh bahwa Lembar Kerja Siswa (LKS) berbasis problem based learning pada materi Bilangandalam kategori praktis.

\section{DAFTAR PUSTAKA}

Abidin, Y. 2014. Desain Sistem Pembelajaran Dalam Konteks Kurikulum 2013. Bandung: Refika Aditama.

Adinawan, M. Cholik dan Sugiyono. 2006. MATEMATIKA SMP Kelas VII. Jakarta: Erlangga.

Akbar, Sa'ud. 2013. Instrumen Perangkat Pembelajaran. Bandung: PT. Remaja.

Ali, Muhammad dan Muhammad Asrori. 2014. Metodologi \& Aplikasi Riset Pendidikan. Bandung: Bumi Aksara

Arikunto, S. 2010. Prosedur Penelitian Suatu Pendekatan Praktik. Jakarta: Rineka Cipta

Aufika, Hasnan. 2015. Pengembangan Perangkat Pembelajaran Matematika Berbasis Problem Based Learning (PBL) pada Materi Perbandingan dan Skala Untuk Meningkatkan Kemampuan Pemecahan Masalah Siswa SMP Kelas VII. Skripsi. Universitas Negeri Yogyakarta

Branch, R. 2009. Instructional Design: The ADDIE Approach. Springer. USA

Kemdikbud. 2014. Matematika Buku pelajaran Siswa. Jakarta: Kemdikbud

Lestari, Ika. 2013. Pengembangan Bahan Ajar Berbasis Kompetensi. Jakarta: Akademia

Mulyatiningsih, Endang. 2011. Metode Penelitian Terapan Bidang Pendidikan. Yogyakarta: Alfabeta

Mulyasa, H. E. 2014. Guru dalam Implementasi Kurikulum 2013. Bandung: PT Remaja Rosda karya.

Ngalimun. 2015. Strategi dan Model Pembelajaran. Banjarmasin: Aswaja Pressindo

Nugroho, Nanang Budi. 2014. Pengembangan RPP dan LKS Berbasis Problem Based Learning (PBL) pada Materi Himpunan Untuk Siswa Kelas VII. Skripsi. Universitas Negeri Yogyakarta

Prastowo, Andi. 2011. Panduan Kreatif Membuat Bahan Ajar Inovatif. Yogjakarta: DIVA Press

Prawiradilaga, Dewi Salma. 2008. Prinsip Desain Pembelajaran. Jakarta: Prenada Media Group

Putra, Juma de. 2013. Inspirasi Mengajar. Jogjakarta: DIVA Press Riduwan.2012. Belajar Mudah Penelitian untuk Karyawan dan Peneliti Pemula. Alfabeta: Bandung

Rusman. 2012. Model-model Pembelajaran. Bandung: PT. Rajagrafindo Persada

Sudjana. 2005. Metoda Statistika. Bandung: Tarsito Sugiyono. 2013. Metode Penelitian Pendidikan Kualitatif Kuantitatif dan $R \& D$. Bandung. Alfabeta

Sunardi. 2015. LKS Pendamping Belajar Siswa Ratih. Jakarta: Singkawang.

Suprijono, Agus. 2009. Cooperative Learning. Surabaya: Pustaka Pelajar

Suraso, Asih. dkk 2012. Buku Siswa Matematika untuk SMP/MTS KelasVII. Widya Duta

Tegeh, I Made, dkk. 2014. Model 
Penelitian Pengembangan.

Yogyakarta: Graha Ilmu.

Trianto. 2007. Model Pembelajaran

Terpadu dalam Teori dan Praktek.

Surabaya: Prestasi Pustaka

Yeni, Arina. 2015. Matematika untuk

SMP/MTS. Klaten: Intan Pariwara 